The Grande Duchesse accompanied the yachts over the course, and the momentary details of the race, as observed from her decks, were flashed to the cable ship, from which they were sent over the cable to New York, and thence telegraphed throughout the world."

Before leaving the United States Mr. Marconi gave some demonstrations of his system to naval officers and technical experts appointed to report upon its value in naval warfare. With the instruments he had available, perfect communication was kept up between the cruiser New York and the battleship Massachusetts when the vessels were thirty-five miles apart; and messages were exchanged over a distance of ten miles with a torpedo boat travelling at full speed.

An even more striking demonstration of the utility of wireless telegraphy was given as we went to press last week. It appears from a letter communicated by Major Flood Page to the Times, that when Mr. Marconi left New York he cabled to the office of his company in London that he would speak to the Needles from the steamship St. Paul on their arrival in English waters. The vessel was expected to pass the Needles about Io or II o'clock on Wednesday morning, and Major Flood Page arrived there on the previous evening, when all arrangements for communication were made. On Wednesday morning, he writes :

"We sent out our signals over and over again, when, in the most natural and ordinary way, our bell rang. It was $2.45 \mathrm{p} . \mathrm{m}$. 'Is that you, St. Paul?' 'Yes.' 'Where are you?' 'Sixty-six nautical miles away.' Need I confess that delight, joy, satisfaction swept away all nervous tension, and in a few minutes we were transcribing, as if it were our daily occupation, four cablegrams for New York, and many telegrams for many parts of England and France, which had been sent fifty, fortyfive, forty miles ' wireless,' to be despatched from the Totland Bay Post Office."

Upon the vessel itself a Transatlantic Times was printed by the ship's compositor, and the subjoined extract from this novel newspaper is of interest in connection with that given above :

"Through the courtesy of Mr. G. Marconi, the passengers on board the St. Paul are accorded a rare privilege-that of receiving news several hours before landing. Mr. Marconi and his assistants have arranged for working the apparatus used in reporting the yacht race in New York, and are now receiving despatches from their station at the Needles. War news from South Africa and home messages from London and Paris are being received. The most important despatches are published on the opposite page. As all know, this is the first time that such a venture as this has been undertaken. A newspaper published at sea with wireless telegraph messages received and printed on a ship going 20 knots an hour! This is the 52 nd voyage eastward of the St. Paul. There are 375 passengers on board, counting the distinguished and extinguished. The days runs have been as follows:-November 9, 435; November IO, 436 ; November I I, 425 ; November I 2, 424; November I3, 431; November 14, 414; November 15, 4I2; 97 miles to Needles at I2 o'clock, November 15. Bulletins:-1.50 p.m. ..... First signal received, 66 miles from Needles. 2.40.'Was that you, St. Paul'? 50 miles from Needles. 2.50.Hurrah! Welcome home! Where are you? 3.30.-40 miles. Ladysmith, Kimberley, and Mafeking holding out well. No big battle. I5,000 men recently landed. 3.40.-At Ladysmith no more killed. Bombardment at Kimberley effected the destruction of one tin pot. It is felt that period of anxiety and strain is over, and that our turn has come. 4.0.- Sorry to say the U.S.A. cruiser Charleston is lost. All hands saved."

In addition to the messages above-mentioned, the Times states that passengers availed themselves of the instruments to send greetings to friends in England and America, and when the St. Paul was forty miles from shore in one case arrangements were completed by a passenger for a supper party in town upon the night of the arrival of the American Line express at Waterloo Station.

NO. I 569, VOL. 6I]
This interesting development of wireless telegraphy solves the problem of the communication of a ship with the shore, so far as ocean liners are concerned; for there should be no difficulty in installing the necessary apparatus, or in training officers to work it. Now that such results have been obtained, advantage should be taken of the system as a means of communication whenever opportunity affords.

\section{SOME RECENT WORK OF THE MARINE BIOLOGICAL ASSOCIATION.}

$\mathrm{NE}$ of the most important tasks which can be undertaken by the staff of a sea-side laboratory is the exact description of the relations between the fauna of the neighbourhood and the external conditions. Excellent anatomical work can be performed, as it is habitually performed in all the various marine stations which now exist, by naturalists who are unable to live continuously at the sea-side. In many cases a short visit to a suitable locality will enable an anatomist, aided by the knowledge and experience of skilled residents, to collect in a short time material for the most complete study of a species from the anatomical point of view. But many complicated problems connected with the breeding of marine animals, and others, equally complex, which arise from even the most superficial study of their distribution, can only be solved by continued observation extending in many cases over years; and such observations can only be conducted by resident naturalists, with the resources of a properly equipped laboratory at their command.

It is well known that officers of the Marine Biological Association have for years been engaged in the study of questions connected with the breeding of fishes and other marine animals. The last number of the Association's Journal contains a report of some 180 pages, illustrated by sixteen charts, which shows that Mr. Allen, the Director of the Plymouth Laboratory, is fully alive to the need for continuous and careful study of the way in which the fauna of the neighbourhood is distributed.

The report deals with the strip of sea-bottom which runs from a point just west of the Eddystone Lighthouse to the Start, at a depth of from about 28 to about 35 fathoms.

A careful description of the nature of the sea-bottom throughout this area is given, and a useful suggestion is made as to the possibility of a uniform nomenclature, by which descriptions of the character of a sea-bottom may be made more clearly intelligible than they are at present.

The bottom deposit is washed through a series of sieves, with apertures varying from 15 millimetres to $0.5 \mathrm{~mm}$. ; and a distinct name is given to the material which rests upon each of these sieves, if the deposit is washed through them in order. Six kinds of material are thus recognised, from "stones," which will not pass through a sieve with perforations of $15 \mathrm{~mm}$. diameter, to "medium sand" which remains on a sieve with a mesh of $0^{*} 5 \mathrm{~mm}$. The material which passes through apertures of $0^{\circ} 5 \mathrm{~mm}$. diameter is separated into two portions by being shaken up in sea-water. Anything which settles in one minute is spoken of as "fine sand," anything which remains in suspension after one minute is spoken of as "silt."

When a deposit has been separated in this way into constituents of different degrees of fineness, the various constituents are dried and weighed, and the weight of each, expressed as a percentage of the total weight of the sample of deposit, is given for each locality.

This method of describing the texture of a sample of the sea-bottom is simple, and not very laborious. The general adoption of such a method would certainly make it easier than it is at present to compare descriptions by various writers. 
A short geological account of the various sands and gravels obtained is given by $\mathrm{Mr}$. R. H. Worth, together with a determination of the $\mathrm{CaCO}_{3}$ (which in these deposits is nearly all of organic origin) in deposits of varying degrees of fineness. Several partial analyses of silts are also given.

Mr. Allen clearly appreciates the great importance of the character of the silt, which forms so large a part of the food of many creatures living on the sea-bottom, and it is to be hoped that in course of time he may be able to attempt a systematic survey of the silts in the neigh. bourhood of Plymouth, so as to tell us not only more about their chemical composition, but more about their physical character, and about the organisms they contain. He has already made an important advance in our knowledge by showing that "coccoliths" occur in shallow water deposits very much more frequently than has hitherto been believed; but many other organisms, such for example as the the various bacteria which exist in these deposits, are likely to be of considerable importance as part of the biological environment; and of these we know practically nothing.

Having given a detailed description of the nature of the sea-bottom at eighteen selected places in the small area dealt with, Mr. Allen gives a complete list of the species obtained at each locality as the result of a number of dredgings, together with an estimate of the relative abundance of the various species. This complicated information has been admirably digested, and it is so tabulated that the reader can see with very little trouble the relation between the abundance of any species and the character of the bottom deposits or of the fauna of adjacent localities.

The work is deliberately linited to a small area, where the conditions of life are tolerably uniform throughout, and statements are made which lead one to hope that this is only a first instalment of a more extended survey.

Every one who cares about the problems of marine zoology will hope that Mr. Allen may be able before very long to publish his promised account of the region between the thirty-fathom line and the shore, so that the relation between the littoral fauna and the fauna he has now described may be determined. As it stands, however, his work is a solid and valuable contribution to a kind of knowledge which must be largely increased before we can hope to understand the bionomics of the sea.

\section{THE OLD RED SANDSTONE OF SHETLAND.}

THOUGH abounding in ill-preserved plant remains, the Old Red Sandstone rocks of Shetland have hitherto yielded none of those characteristic fossil fishes which would enable us to compare them with rocks of similar age elsewhere in Scotland. On the general evidence of lithological features and the supposed identity of their respective floras, they have been regarded usually as a northward extension of the "Orcadian" beds of Caithness and the Orkneys. Two years ago Mr. John S. Flett, M.B., B.Sc., of Edinburgh University, was able to report that he had found certain obscure fish remains in Shetland, and, this summer, assisted by a grant from the Royal Society of London to defray the expenses of quarrying, he has succeeded in obtaining a number of undoubted fish-remains from the flag-stones of Brissay, near Lerwick. In this collection, which consists mostly of broken and detached plates, Dr. R. H. Traquair, F.R.S., has recognised fragments of an Asterolepis (probably a new species) and of Holonema, a fish new to Britain, but occurring in the Chemung (Upper Devonian) of North America. A full description of these will, no doubt, shortly be forthcoming. In the meantime, it seems certain that the fauna of these beds NO. I 569 , vOL. 61 ] is distinct from any fauna of Old Red age at present known in Britain, and, until more fully investigated, its horizon remains open to question ; but $\mathrm{Mr}$. Flett inclines to believe that its real position will turn out to be intermediate between the John-o'-Groat's beds (the highest of the Orcadian series of the Orkneys) and the true Upper Old Red of Moray and Elgin. The genus Asterolepis, so characteristic of the Upper Old Red, was shown by him two years ago to occur also in the Thurso beds of the Orkneys, and the general forms of the Shetland flora would indicate a connection with the Orcadian. Nevertheless, the whole aspect of the fauna is Upper Old Red ; not one of the commoner Orcadian fishes has been obtained in Shetland. An interesting problem is opened up by these discoveries, to which it is to be hoped further investigations will furnish a definite solution.

$$
\begin{gathered}
\text { SIR J. WILLIAM DAWSON, C.M.G., LL.D., } \\
\text { F.R.S., \&oc. }
\end{gathered}
$$

NEWS has been received of the death of Sir William Dawson, Emeritus Principal and Chancellor of McGill University, Montreal, and the most distinguished of Canadian geologists. He was the son of James Dawson, of Picton, a town on the northern shores of Nova Scotia, where he was born in October 1820 .

Coming to this country in early youth he studied at the University of Edinburgh, and gained a knowledge of geology and allied sciences from Robert Jameson, then Regius Professor of Natural History. Returning to his native land, Dawson became Superintendent of Education in Nova Scotia from 1850 to 1853 ; and later on Professor of Geology and Principal of McGill College and University I 855 to I 893 .

On his return to Nova Scotia he directed his attention with the greatest enthusiasm to the study of geology, for as early as 1845 we find him communicating to the Geological Society of London papers on the Coal-formation of the country. To this formation for many years he gave especial study. In company with Sir Charles Lyell he made in 1852 a detailed examination of the fine succession of "fossil forests" of the Coal-period in the cliffs of South Joggins. Together they obtained" also the first remains in the Coal-measures of an "airbreathing reptile," named Dendrerpeton, which was found in the interior of one of the erect Sigillarix; a single species of land-shell, Pupa vetusta, was found in the same situation.

Zealously pursuing his observations, Dawson was enabled to issue in 1855 his well-known work entitled "Acadian Geology: an account of the Geological Structure and Mineral Resources of Nova Scotia." A third edition of this work was published in 1878 .

In 1854 he became a Fellow of the Geological Society of London, and it is noteworthy that all his leading discoveries, before and afterwards, were brought before this Society. His contributions to geological science were many, and though dealing largely with fossil plants, with footprints and impressions of various animals, he also wrote concerning the higher forms of life, and devoted much attention to the phenomena of the Glacial period.

In 1862 Dawson was elected a Fellow of the Royal Society. Two years later his name was rendered familiar to every student of geology by the announcement of the discovery of an organism in the oldest known rocks, the Laurentian of Canada. As early as I859 Sir William Logan had expressed his opinion that traces of organic structure were to be found in Laurentian limestone; but it was not until 1864 that Dr. Dawson determined by the aid of the microscope that the structure was that of a Foraminifer. He then gave to the "fossil" the name Eozoon Canadense, and his opinion was strongly 